\title{
CORRELATION BETWEEN BODY MEASUREMENTS AND MILK PRODUCTION OF GOATS IN DIFFERENT LACTATIONS
}

\author{
M. Žujović ${ }^{1}$ N. Memiší ${ }^{2}$, V. Bogdanović ${ }^{3}$, Z. Tomić ${ }^{1}$ \\ ${ }^{1}$ Institute for Animal Husbandry, Autoput 16, 11080 Belgrade-Zemun, Republic of Serbia \\ ${ }^{2}$ AD "Mlekara", Tolminska 10, 24000 Subotica, Republic of Serbia \\ ${ }^{3}$ Faculty of Agriculture, Nemanjina 6, 11080 Belgrade-Zemun, Republic of Serbia \\ Corresponding author: zotom@mail.com \\ Original scientific paper
}

\begin{abstract}
This paper presents the results of the variability and correlation of body measurements and milk production of domestic Balkan goat breed that is reared in the mountain range Sharplanina, depending on the lactation. Studied animals were monitored and lactation, or order of kidding (I, II, III and IV and the next lactation together). Control of milk production, included a total of 290 goats in different lactations (first-81 animals, the second-69 heads, 71 heads third-and fourth and following along latkacije-69 heads). In order to determine the measure of body development in adult goats, one takes values for height at withers, body length, chest depth, chest width, the width of the cross and body weight. The variability of the analyzed characteristics is presented descriptive parameters and the effect of lactation is determined by a factorial analysis of variance. The determined average values for milk production and measures of body development are located within those identified for this population of goats. During these tests showed statistically significant correlation dependence $(\mathrm{P}<0.05)$ between all studied variables, except when it comes to length lactation period and individual measures of body development. The correlation coefficient between length of lactation and established measures of body development. are low and reflect the existence uncorrelation dependence, and their values range from 0.08 to 0.11 , while they were unjustified and statistically $(\mathrm{P}>0.05)$.
\end{abstract}

Key words: balkan goat, milk production, body development, stage of lactation, correlation

\section{Introduction}

The succes of selection in production of goat milk depends not only on direct improvement of the milk traits/performance (milk yield, content of milk fat or 
proteins), but also on improvement of other traits, such as body development or functional characteristics which also contribute to improvement of the production efficiency. Therefore, it is necessary to include into the program of improvement of goat milk production through selection measures also those traits which have direct but also indirect impact on this production, such as the traits of body development.

Today, so called linear type and body condition scoring based on visual evaluation of animal according to already determined instructions and standards is generally accepted. In this way certain qualitative traits are transfered into quantitative which enables their statistical processing and analysis. On the other hand, determination of absolute body dimensions is also very important, because they represent morphological and physiological basis not only for linear scoring of body development, but also for optimal expression of production and reproduction traits. Therefore, the knowledge of the correlation between the body development and milk performance in goats is important (Riva et al., 2002).

Phenotype correlations, i.e. correlation between certain traits in goats were studied by numerous authors. Biometrical measuring provides significant information on course of growth of goats or expression of certain traits. In addition, body development of goats and phenotypic expression of milk performance are very important sources of data used in the control of the standards for certain breed (Riva et al., 2002).

Evaluation of goats is based on the expression of their production traits. Therefore, there is the need for assessment of traits, starting with simple traits which can easily be measured (linear body dimensions or milk performance) to the complex ones (Singh and Mishra, 2004; Khan et al., 2006).

Therefore, the objective of this study was to present the impact of the order of lactation on variability and correlation of body development and milk performance in Balkan goat breed. This breed was chosen for this research because of it's importance in goat breeding in Serbia, considering that it still represents the largest goat population (approx. 35\% of total population).

\section{Materials and Methods}

The research material used in this study were goats of Balkan breed from the territory of northwestern part of the mountain range Šarplanina. Control of production performance included goats of red colour, as authentic representatives of the Domestic Balkan goat. Studied animals were observed in lactations, i.e. order of partus (I, II, III, and IV and subsequent lactations together).

The control of milk performance included total of 290 goats in different lactations (the first - 81 animals, the second - 69 animals, the third - 71 animals, and the fourth and subsequent lactations together - 69 animals). Quantity of 
produced milk in all goats was determined $10^{\text {th }}$ day subsequent to partus, at the latest, until the end of lactation (dry off period). All animals were in A control. Measuring of the quantity of milked milk was done using graduated cylinders, with the smallest division of $10 \mathrm{ml}$.

Measuring of the body development of goats was done at the beginning of September. The following main exterior measures were recorded: height of withers (HW), carcass length (CL), breast depth (BD), breast width (BW), rump width (RW), as well as body mass (BM). Body mass was recorded in adult goats using individual technical weight scale of accuracy of $100 \mathrm{~g}$, and body measurements were determined using Lydtin stick/rod.

Variability of analyzed traits was described using parameters of descriptive statistics, correlation between traits was determined by correlation coefficient, whereas the effect of order of lactation was tested using single factor variance analysis.

\section{Results and Discussion}

Table 1 presents basic parameters of descriptive statistics for milk yield and individual measures of body development in Balkan goats. Based on obtained data it was established that the average duration of lactation period in Domestic Balkan goat was 230 days, i.e. approx. 8 months, which is slightly shorter lactation compared to value determined by Bogdanović et al. (2008). Based on the value of standard deviation $(\mathrm{SD}=26,85)$ it is noticeable that the duration of lactation was very uneven which is result of unequal time of kidding from February to May.

Table 1. Average values and variability of milk performance and measures of body development of goats

\begin{tabular}{|l|c|c|c|c|c|}
\hline Traits & $\mathrm{N}$ & $\mathrm{M}$ & Minimum & Maximum & SD \\
\hline Duration of lactation (day) & 290 & 230.1 & 142.00 & 287.00 & 26.85 \\
\hline Height to withers (cm) & 290 & 66.27 & 57.00 & 75.00 & 3.39 \\
\hline Body length $(\mathrm{cm})$ & 290 & 69.91 & 58.00 & 80.00 & 4.32 \\
\hline Breast width $(\mathrm{cm})$ & 290 & 16.84 & 13.50 & 21.00 & 1.39 \\
\hline Breast depth $(\mathrm{cm})$ & 290 & 29.90 & 24.00 & 35.50 & 2.26 \\
\hline Hip width $(\mathrm{cm})$ & 290 & 17.40 & 14.00 & 22.00 & 1.25 \\
\hline Body mass $(\mathrm{kg})$ & 290 & 38.32 & 23.00 & 64.00 & 7.46 \\
\hline Milk yield $(\mathrm{kg})$ & 290 & 169.52 & 71.90 & 321.80 & 46.86 \\
\hline
\end{tabular}

Legend: $\mathrm{M}=$ Average, $\mathrm{SD}=$ Standard deviation.

Milk performance/yield of the Balkan goat is relatively less expressed compared to pure breeds, even improved transitional breeds. Slightly lower milk yield of Balkan goat was established by Marković (1997) in the analysis of 
production results from 6 private farms in Montenegro. Average milk yield of Balkan goat in this research was approx. $129 \mathrm{~kg}$, but with somewhat shorter third lactation of around 218 days. However, compared to local, primitive breeds reared in other parts of Europe or world, milk performance of Balkan goat is expressed within expected biological limits for this breed group. In more extensive analysis of the possibilities to use high productive breeds as meliorators in flocks of local, primitive breeds, Serradilla (2001) stated that the milk performance of autochthonous Italian breeds and Maltese breeds ranged from 135 to $360 \mathrm{~kg}$, of Greek breeds from 100 to $180 \mathrm{~kg}$ and Turkish local goat breeds from 120 to 400 $\mathrm{kg}$. On the other hand, milk performance of Spanish breeds ranged from 425 to 650 $\mathrm{kg}$ and lactation period from 200 to 260 days were presented by Haenlein (2007) in the critical review of the contemporary development of sheep and goat milk production (Bogdanović et al., 2008).

In Table 2. the average results concerning the milk performance and duration of lactation in Balkan goats depending on the order of lactation are presented. The average quantity of milk in goats in their first lactation was $138,68 \mathrm{~kg}$, aand it increased in subsequent lactations, so in the fourth and later lactations the milk yield was around $192,51 \mathrm{~kg}$. Similar trend in expression of milk traits in different lactations was established by Bogdanović et al. (2010).

Table 2. Milk yield and duration of lactation in Balkan goat depending on the order of lactation

\begin{tabular}{|c|c|c|c|c|c|}
\hline \multirow{2}{*}{ Order of lactation } & \multirow{2}{*}{$\mathrm{N}$} & Duration of lactation & Milk yield & \multicolumn{2}{|c|}{} \\
\cline { 3 - 4 } & & $\mathrm{M}$ & $\mathrm{SD}$ & $\mathrm{M}$ & $\mathrm{SD}$ \\
\hline L1 & 81 & 227.00 & 26.79 & 138.69 & 27.91 \\
\hline L2 & 69 & 228.33 & 28.27 & 168.10 & 48.43 \\
\hline L3 & 71 & 229.59 & 28.64 & 183.74 & 47.01 \\
\hline L4 & 69 & 236.01 & 22.95 & 192.51 & 43.73 \\
\hline Average & 290 & 230.09 & 26.85 & 169.52 & 46.86 \\
\hline
\end{tabular}

Legend: $\mathrm{M}=$ Average, $\mathrm{SD}=$ Standard deviation

Table 3. presents average results of body development in Balkan goats depending on the order of lactation. According to lactations, average values for certain measures of body development increased from the first lactation to the fourth and later lactations, where the lowest value of all measures of body development, as well as body mass, was recorded in the first lactation, whereas in the fourth and later lactations this value increased. 
Table 3. Body development of Balkan goats depending on the order of lactation

\begin{tabular}{|c|c|c|l|l|l|l|l|l|l|l|l|}
\hline \multirow{2}{*}{$\begin{array}{c}\text { Order of } \\
\text { lactation }\end{array}$} & \multirow{2}{*}{$\mathrm{N}$} & \multicolumn{2}{|c|}{$\begin{array}{c}\text { Height to } \\
\text { withers }\end{array}$} & \multicolumn{2}{c|}{ Body length } & \multicolumn{2}{c|}{ Breast width } & \multicolumn{2}{c|}{ Breast depth } & \multicolumn{2}{|c|}{ Body mass } \\
\cline { 3 - 14 } & & $\mathrm{M}$ & $\mathrm{SD}$ & $\mathrm{M}$ & $\mathrm{SD}$ & $\mathrm{M}$ & $\mathrm{SD}$ & $\mathrm{M}$ & $\mathrm{SD}$ & $\mathrm{M}$ & SD \\
\hline L1 & 81 & 63.38 & 2.66 & 65.81 & 3.29 & 15.87 & 0.87 & 27.75 & 1.36 & 30.75 & 3.97 \\
\hline L2 & 69 & 66.18 & 3.05 & 70.00 & 3.75 & 16.65 & 1.17 & 29.53 & 2.01 & 36.86 & 4.77 \\
\hline L3 & 71 & 67.71 & 2.97 & 72.00 & 3.26 & 17.26 & 1.27 & 30.71 & 1.36 & 41.85 & 5.68 \\
\hline L4 & 69 & 68.26 & 2.4 & 72.45 & 3.23 & 17.72 & 1.45 & 31.94 & 1.69 & 45.02 & 5.72 \\
\hline Average & 290 & 66.27 & 3.38 & 69.90 & 4.32 & 16.84 & 1.38 & 29.90 & 2.25 & 38.32 & 7.45 \\
\hline
\end{tabular}

Legend: $\mathrm{M}=$ Average, $\mathrm{SD}=$ Standard deviation

In regard to body mass, variation of the average value according to lactation was more distinct $(5,72 \%)$ in fourth compared to the first lactation $(3,97 \%)$. In regard to data obtained on the average body mass of goats in the fourth lactation $(45,02 \mathrm{~kg})$, it is obvious that it is higher in average than the body mass of goats in the first lactation by approx. $15 \mathrm{~kg}$. Low body mass of goats, primarily in the first lactation, is partially consequence of worsle conditions relating to nutrition and care, especially of progeny which are introduced to breeding with unfinished growth and insufficient body mass, and these consequences are suffered by animals all their life (Memiši 2000; Khan et al., 2006). Obtained values for certain body measures in studied population of Domestic Balkan goat are at the level of results obtained by Khan et al. (2006) for body mass, height to withers and body length for Bettal goat breed reared in pakistan, as well as Ahmed et al. (2004) for Barki goats in Egypt. Higher values for measures of body development compared to our study are stated by Helal (2009) for Damaskus breed goats reared in Egypt.

Table 4 presents results of the variance analysis of the effect of order of lactation on milk performance and body development measures in Balkan goats.

Table 4. The effect of order of lactation on variability of traits

\begin{tabular}{|c|c|c|c|c|c|c|c|c|}
\hline Trait & $\begin{array}{c}\text { Sum of the } \\
\text { square of } \\
\text { model }\end{array}$ & $\begin{array}{c}\text { Degree of } \\
\text { fredoom } \\
\text { of the } \\
\text { model }\end{array}$ & $\begin{array}{c}\text { Mean of } \\
\text { the square } \\
\text { of model }\end{array}$ & $\begin{array}{c}\text { Sum of the } \\
\text { square of the } \\
\text { error }\end{array}$ & $\begin{array}{c}\text { Degree of } \\
\text { fredoom of } \\
\text { the error }\end{array}$ & $\begin{array}{c}\text { Mean of } \\
\text { the square } \\
\text { of error }\end{array}$ & F & $\mathrm{p}$ \\
\hline $\begin{array}{c}\text { Duration of } \\
\text { lactation }\end{array}$ & 3425.8 & 3 & 1141.94 & 204951.5 & 286 & 716.614 & 1.59 & $\mathrm{~ns}$ \\
\hline HW & 1098.3 & 3 & 366.09 & 2222.5 & 286 & 7.771 & 47.11 & $* * *$ \\
\hline CL & 2119.7 & 3 & 706.56 & 3285.6 & 286 & 11.488 & 61.50 & $* * *$ \\
\hline BW & 144.5 & 3 & 48.17 & 411.2 & 286 & 1.438 & 33.50 & $* * *$ \\
\hline BD & 719.8 & 3 & 239.93 & 750.7 & 286 & 2.625 & 91.41 & $* * *$ \\
\hline RW & 83.3 & 3 & 27.77 & 371.8 & 286 & 1.300 & 21.36 & $* * *$ \\
\hline BM & 8763.8 & 3 & 2921.28 & 7307.2 & 286 & 25.550 & 114.33 & $* * *$ \\
\hline Milk yield & 127964.5 & 3 & 42654.82 & 506542.6 & 286 & 1771.128 & 24.08 & $* * *$ \\
\hline
\end{tabular}

Legend: Significance *** $\mathrm{P}<0.001$. 
Differences in milk performance traits and body development measures established under the influence of order of lactation were highly significant at the level of $P<0,001$ for all analyzed traits, except duration of lactation, which was not under the statistically significant influence of order of lactation $(P>0,05)$.

Table 5 presents data on the magnitude of correlation of studied traits of body development and milk performance in Domestic Balkan goats. Between all studied traits, with the exception of duaration of lactation period and certain measures of body development, statistically significant correlation was determined $(P<0,05)$.

Table 5. Results relating to study of the strenght of correlation between certain body development measures and milk performance of goats

\begin{tabular}{|c|c|c|c|c|c|c|c|c|}
\hline Trait & $\begin{array}{c}\text { Duration } \\
\text { of } \\
\text { lactation }\end{array}$ & $\mathrm{HW}$ & $\mathrm{CL}$ & $\mathrm{BW}$ & $\mathrm{BD}$ & $\mathrm{RW}$ & $\mathrm{BM}$ & $\begin{array}{c}\text { Milk } \\
\text { yield }\end{array}$ \\
\hline $\begin{array}{c}\text { Duration } \\
\text { of } \\
\text { lactation }\end{array}$ & 1.00 & $0.08^{\mathrm{NS}}$ & $0.11^{\mathrm{NS}}$ & $0.17^{*}$ & $0.09^{\mathrm{NS}}$ & 0.12 & $0.10^{\mathrm{NS}}$ & $0.51^{*}$ \\
\hline $\mathrm{HW}$ & $0.08^{\mathrm{NS}}$ & 1.00 & $0.78^{*}$ & $0.51^{*}$ & $0.75^{*}$ & $0.54^{*}$ & $0.78^{*}$ & $0.37^{*}$ \\
\hline $\mathrm{CL}$ & $0.11^{\mathrm{NS}}$ & $0.78^{*}$ & 1.00 & $0.61^{*}$ & $0.82^{*}$ & $0.63^{*}$ & $0.83^{*}$ & $0.46^{*}$ \\
\hline $\mathrm{BW}$ & $0.17^{*}$ & $0.51^{*}$ & $0.61^{*}$ & 1.00 & $0.66^{*}$ & $0.76^{*}$ & $0.69^{*}$ & $0.48^{*}$ \\
\hline $\mathrm{BD}$ & $0.09^{\mathrm{NS}}$ & $0.75^{*}$ & $0.82^{*}$ & $0.66^{*}$ & 1.00 & $0.69^{*}$ & $0.84^{*}$ & $0.49^{*}$ \\
\hline $\mathrm{RW}$ & $0.12^{*}$ & $0.54^{*}$ & $0.63^{*}$ & $0.76^{*}$ & $0.69^{*}$ & 1.00 & $0.70^{*}$ & $0.48^{*}$ \\
\hline $\mathrm{BM}$ & $0.10^{\mathrm{NS}}$ & $0.78^{*}$ & $0.83^{*}$ & $0.69^{*}$ & $0.84^{*}$ & $0.70^{*}$ & 1.00 & $0.48^{*}$ \\
\hline $\begin{array}{c}\text { Milk } \\
\text { yield }\end{array}$ & $0.51^{*}$ & $0.37^{*}$ & $0.46^{*}$ & $0.48^{*}$ & $0.49^{*}$ & $0.48^{*}$ & $0.48^{*}$ & 1.00 \\
\hline
\end{tabular}

Legend: $\mathrm{HW}=$ height to withers; $\mathrm{CL}=$ carcass length; $\mathrm{BW}=$ breast width; $\mathrm{BD}=$ breast depth; $\mathrm{RW}=$ rump width; $\mathrm{BM}=$ body mass. Significance: $\mathrm{NS}=$ not significant; $* \mathrm{P}<0,05$

Similar values for correlation coefficients are stated in the research by Marković (1997) who established the presence of complete correlation between duration of lactation and total milk quantity $(\mathrm{P}<0,01)$. Iloeje and Van Vleck (1978) stated that the phenotypic correlation between the quantity of milk during the lactation period and body mass in Don goat was 0,39 , and in German improved goat 0,132 . Similar values of correlation coefficients between body mass and milk performance $(0,36)$ were stated by Gall (1980) in the study of the German improved goat, and Semakula et al. (2010) in local goat breeds reared in Ugandi.

By investigating the phenotype connection between body mass and some body measures of Domestic white goat and its crosses $F_{1}$ generation with Saanen goat from Bulgaria and Switzerland, as well as the influence of different factors on their 
expression and variation, Žujović et al. (1991, 1993) established positive and statistically very significant correlations $(\mathrm{R}<0,01)$ between body mass and height to withers, breast girth and shank circumference, as well as height to withers and breast girth and shank circumference. Mentioned authors stated that the most distinct connection was determined between the body mass and breast girth in all three genotypes $(0,708,0,833$ i 0,788). Also, Pesmen and Yardimci (2008) stated the statistically significant correlation between certain body development measures and body mass (from 0.5 to 0.94 ) in goats of Saanen breed which were at the similar level like in this research. Nemeth et al. (2009) established medium and very strong $(\mathrm{P}<0,01)$ correlation between body mass and body development measures in different breeds reared in Hungary.

\section{Conclusion}

Based on results of the investigation of the effect of lactation on variability and correlation between body development traits and milk performance in Balkan breed goats, the following can be concluded:

It was established that average duration of lactation period in Domestic Balkan goat was 230,09 days, i.e. approximately 8 months. Average milk yield in goats in the first lactation was $138,68 \mathrm{~kg}$, and it increased in subsequent lactations, so in the fourth lactation the milk yield was $192,51 \mathrm{~kg}$.

Differences established under the influence of order of lactation were significant at the level of $P<0,001$ for all anlyzed traits og body development and milk performance, except for duration of lactation.

The magnitude of correlation between studied traits of body development and milk performance in domestic Balkan goats statistically was significant $(\mathrm{P}<0,05)$ between all observed parameters, except duration of lactation and certain body development measures.

\section{Acknowledgment}

Research was financed by the Ministry of Education and Science Republic of Serbia, project TR 31053. 


\title{
Povezanost telesne razvijenosti i mlečnosti koza u različitim laktacijama
}

\author{
M. Žujović, N. Memiši, V. Bogdanović, Z. Tomić
}

\section{Rezime}

U radu su prikazani rezultati ispitivanja varijabilnosti i povezanosti osobina telesne razvijenosti i mlečnosti domaće balkanske rase koza u zavisnosti od laktacije po redu (I, II, III a IV i naredne laktacije zajedno). Kontrolom proizvodnje mleka bilo je obuhvaćeno ukupno 290 koza u različitim laktacijama (prva- 81 grla, druga- 69 grla, treća- 71 grla, a četvrta i naredne latkacije zajedno69 grla). U cilju utvrđivanja mera telesne razvijenosti odraslih koza izmerene su vrednosti za visinu grebena, dužinu trupa, dubinu grudi, širinu grudi, širinu krsta i telesnu masu. Varijabilnost analiziranih osobina opisana je parametrima deskriptivne statistike, a uticaj laktacije po redu je utvrđen jednofaktorijalnom analizom varijanse. Utvrđene prosečne vrednosti za proizvodnju mleka i mere telesne razvijenosti bile se u okviru onih koje su utvrđene za ovu populaciju koza. Ispitivanjem su utvrđene statistički značajne korelacije $(\mathrm{P}<0,05)$ između svih posmatranih parametara, izuzev kada je u pitanju dužina laktacionog perioda i pojedinih mera telesne razvijenosti koje statistički nisu bile značajne.

\section{References}

AHMED A.M., ABDEL-MONEIM A.Y., SHEHATA M.F., M.M. ABDEL-AZIZ M.M. (2004): Estimating body weight from morphometric measurements of Barki goats raised under semi-arid conditions. Egyptian, J. Anim. Prod., 41, 115-122.

BOGDANOVIĆ, V., PERIŠIĆ P., ĐEDOVIĆ R., POPOVIĆ Z., MIJIĆ P., BABAN M., ANTUNOVIĆ B. (2010): Characteristics of dairy production traits of Balkan goats raised under "low-input" production systems. Mljekarstvo, 60, 1, 30-36. BOGDANOVIĆ V., ĐORĐEVIĆ I., ĐURĐEVIĆ I. (2008): Osobine mlečnosti balkanske koze u poluekstenzivnim uslovima gajenja. Biotechnology in Animal Husbandry, 24, 1-2, 59-67.

GALL C. (1980): Relationship between body conformatiion and production in dairy goats. Journal of Dairy science, 63, 10, 1768-1781.

HELAL A. (2009): Body Measurements and Some Coat Characteristics of Shammi (Damascus) Goats Raised in North Sinai, Egypt. World Journal of Agricultural Sciences, 5, 5, 646-650.

ILOEJE M.U., VAN VLECK L.D. (1978): Genetics of dairy goats. A. Review. Jorunal Dairy Sci., 61, 1521-1528. 
KHAN H., MUHAMMAD F., AHMAD R., NAWAZ G., RAHIMULLAH N., ZUBAIR M. (2006): Relationship of body weight with linear body measurements in goats. Journal of Agricultural and Biological Science, 1, 3, 51-54

MARKOVIĆ B. (1997): Proizvodne i reproduktivne osobine važnijih varijeteta domaće balkanske koze u Crnoj Gori. Magistarski rad, Beograd.

MEMIŠI N. (2000): Kvantitativna analiza telesne razvijenosti i proizvodnih osobina domaće balkanske koze. Doktorska disertacija, Poljoprivredni fakultet, Beograd-Zemun.

NEMETH T., KOMLOSI I., MOLNAR A., KUSZA S., LENGYEL A., KUKOVICS S. (2009): Differences between goat breeds based on body measurements in Hungarian populations. Journal Állattenyésztés és Takarmányozás, 58, 4, 353-367.

PESMEN G., YARDIMCI M. (2008): Estimating the live weight using some body measurements in Saanen goats. Archiva Zootechnica, 11, 4, 30-40.

RIVA J., RIZZI R., MARELLI S., CAVALCHINI G. (2002): Body measurements in Bergamasca Sheep, Small Ruminant Research, 51, 221-227

SINGH P.N., MISHRA A.K. (2004): Prediction of body weight using conformation traits in Barbari goats. Indian J. Small Ruminants, 10, 2, 173.

SEMAKULA J., MUTETIKKA D., KUGOMZA R., DONALD V., MPAIRWE D. (2010): Variability in body morphometric measurements and their application in predicting live body weight of mubende and small east African goat breeds in Uganda. Middle-East Journal of Scientific Research, 5, 2, 98-105.

ŽUJOVIĆ M., ŽUJOVIĆ M. (1991): Korelacina povezanost mase tijela i nekih telesnih mera domaće bele koze i njenih meleza sa sanskom kozom. International summer conference for advancement of sheep and goat production. Ohrid.

ŽUJOVIĆ M., ŽUJOVIĆ M. (1993): Fenotipske korelacije izmedju mase tela i nekih telesnih mera u tri genotipa koza. Savremena poljoprivreda, 1-2, IX Seminar o savremenoj stočarskoj proizvodnji, Novi Sad. 